\title{
Research on Promoting the Development of China's Cultural Products Trade Against the Background of Trade War
}

\author{
Jing Gao \\ Shanghai Donghai Vocational and Technical College \\ Shanghai, China 200241
}

\begin{abstract}
In recent years, the economic and trade frictions between the United States and China have been escalating, and the recent fierce economic and trade frictions have been upgraded to the "trade war". Faced with the arrival of the "trade war" between China and the United States, it can really put forward positive and effective countermeasures. This paper will focus on the development of Chinese cultural product trade, based on the development course and present situation of Chinese cultural product trade, against the background of recent "trade war" and China's trade friction in recent years, explore the international competitiveness of Chinese cultural product trade and its influencing factors, and put forward the relevant strategies to promote the development of Chinese cultural product trade from different angles, in order to get a clear understanding of the situation, actively respond to the situation and provide useful reference for promoting the development of China's cultural products trade.
\end{abstract}

Keywords - cultural product trade; development status; trade war; international competitiveness

\section{INTRODUCTION}

In recent years, the economic and trade frictions of the United States against China have been constantly upgraded, and the recent fierce economic and trade frictions have been upgraded to the "trade war". Bai Ming, deputy director and researcher of the International Market Research Institute of the Ministry of Commerce, stated in a publicly published article "Facing the China-US Trade War and Its Response Strategies" that "the arrival of the China-US trade war must be faced up. If the 'trade war' between China and the United States has not been acknowledged, the countermeasures proposed accordingly will not be effective." As Bai Ming said, if the fierce economic and trade frictions are not restrained, they will develop into a "trade war". The reason why the "trade war" between China and the United States is determined is mainly based on the fact that the amount involved exceeds the amount involved in the past economic and trade frictions between countries, that the United States abandons cooperation and continues to use the means of confrontation games to exert extreme pressure, and that it violates the relevant regulations of the world trade organization. [1] the U.S. pursuit of maximizing its own interests not only upgrades the Sino-U.S. economic and trade frictions to "trade wars", but also tries to continue to suppress Chinese products, China's industrial status and even China's international influence in international relations. Therefore, it is necessary to fully recognize the status of "trade wars", under this background, discusses China's foreign trade strategy and the development direction of China's industry and product trade, and then puts forward effective countermeasures. This paper will focus on the development of China's trade in cultural products, based on the development process and current situation of China's trade in cultural products, under the background of recent "trade war" and recent trade frictions in China, discuss the international competitiveness of China's trade in cultural products and its influencing factors, and put forward relevant strategies to promote the development of China's trade in cultural products from different perspectives, in order to get a clear understanding of the situation, actively respond to the situation and provide useful reference for promoting the development of China's cultural products trade.

\section{DeVElopment Process AND CURRENT Situation of ChinA's CUlTuRAL PRODUCTS TRADE}

As for the trade of cultural products, the United Nations has made a clear definition in the International flow of cultural products and cultural services (1994-2003), which refers to "the mode of trade input and output of international cultural products and services". [2]As an important part of international cultural trade, cultural product trade is not only the import and export of cultural consumer goods, but also an important way to spread ideas, promote national culture and enhance international influence. At present, the cultural products in China's foreign trade mainly include books, newspapers, handicrafts, audio-visual products, performance activities, visual arts, etc. the nature of cultural products determines the particularity of cultural products trade, which is mainly reflected in the highly monopolized market of developed countries headed by the United States, the lack of clear and unified international standards and tariff restrictions, which makes the trade barriers have strong concealment, in terms of limited openness of cultural product trade in sensitive areas and easy integration with other international trade industry products, understanding the particularity of cultural product trade has basic value in analyzing the issue of cultural product trade development. 
The development of cultural product trade is based on the development of domestic cultural industry. The development of China's cultural product trade started from the period of reform and opening up in the late 1970s. Before the reform and opening up, strictly speaking, the cultural industry as a tool to serve the mainstream ideology has not really formed and developed. After the reform and opening up, especially from the 1980s to the early 1990s, China's cultural industry began its preliminary development in the wave of national economic recovery and development, economic and cultural system reform, followed by the gradual departure of some Chinese cultural products from the country. In the nineties of the last century, the development of cultural undertakings in China is speeding up day by day. Under the concept of "cultural economy", the relevant policies to promote the development of cultural undertakings are improving day by day, laying the foundation for the transformation of cultural undertakings to cultural industries. In the late 1990s, the scale of China's cultural industry continued to expand, the cultural system was comprehensively reformed, and the cultural market was increasingly standardized. Cultural industry played an increasingly important role in the process of national economic growth and international trade development. Since the new century, China's accession to the world trade organization, with the relaxation of market access conditions, the norms of international trade-related policies, the rapid development of China's cultural products trade, the development of cultural industry groups is also showing a rapid trend. In the past ten years, the international competitiveness of China's cultural products trade has been increasing. Especially since the promulgation of the "revitalization plan for cultural industries", the state attaches great importance to the development of cultural industries, and the scale of exports of cultural products is growing. Under the background of the "going global" strategy and the "one belt and one way" initiative, the pace of China's cultural products trade has never ceased. At present, although the trade of cultural products in China shows a good trend of sustainable development as a whole, it is worth noting that the trade structure of cultural products in China is relatively single, mainly focusing on the export of "hardware" in the fields of entertainment, games, sports, tourism, etc., while the export proportion of cultural products in the fields of film, TV series, music, etc. is low. With the rise of labor cost and the decline of cultural products manufacturing, it will affect the steady and sustainable development of China's cultural products trade. At the same time, the lack of domestic cultural brands and the lack of distinctive national cultural characteristics of cultural products have greatly affected the improvement of the international competitiveness of China's cultural products trade, and also greatly influenced the development of China's cultural products trade by the changes in the international trade environment, especially in the context of the global economic downturn and "trade war", China's export growth of cultural products has fallen from time to time.

\section{ENHANCING THE INTERNATIONAL COMPETITIVENESS OF China's CUlTural PRODUCTS TRADE AND PROMOTING THE DEVElopMENT OF CHINA's CUlTURAL PRODUCTS TRADE}

Against the background of "trade war", to promote the sustainable development of China's cultural products trade, it is necessary to enhance the international competitiveness of China's cultural products trade, and the comprehensive analysis of the international competitiveness of cultural products trade and its influencing factors is an important basis. Michael Porter, an American economist, put forward the theory of national competitive advantage, and analyzed the influencing factors of national competitive advantage in many works such as National competitive advantage. Michael Porter believes that the competitive advantage of a country's enterprises determines its industrial competitive advantage, which in turn determines its national competitive advantage. Starting from the theory of national competitive advantage, it is not difficult to find that industrial development is essential to enhance the international competitiveness of products, enterprises and even countries. Although the promotion of the international competitiveness of a single industry may not necessarily enhance the international competitiveness of a country, However, due to the fact that cultural products are easy to integrate with other international trade products, the promotion of international competitiveness of China's cultural products trade is bound to be of great significance to the promotion of China's international competitiveness in international trade. Michael Porter also put forward the famous "Diamond Model". He believes that the main factors affecting the trade of industrial products are production factors, demand status, strategic organization and competition status of the company, relevant industry support, and the role of the government. At the same time, the external environment and development opportunities also have a significant impact on the development of a country's cultural product trade. [3]

Due to the important role of cultural products in the field of ideology, there are barriers to trade in cultural products in various countries to a certain extent. As a safeguard measure to maintain the leading role of the country's mainstream cultural values and increase the share of domestic cultural products in the domestic cultural market, it is worth noting that this is not the same as the excessive use of economic means, political means or even "trade war" and other means against the rules of international cultural trade to disrupt the trade environment of international cultural products and monopolize the international trade market. For a long time, the United States has always maintained its strong position in the international cultural trade through the so-called liberalization policy in the field of economy, trade and investment, and even tried to monopolize the international trade market by "playing the edge ball" in the process of implementing the rules of international cultural trade to monopolize the international trade market, constantly enhancing the publicity of foreign culture, escorting "imperialism" by exporting American cultural values strongly. In this context, the pressure of the development of China's cultural product trade is huge, especially since the "trade war", including cultural products, China's product trade is suffering greater development resistance, fully analyze the current situation of China's cultural product trade and the impact factors of its international competitiveness, and put forward targeted strategies to promote the development of China's cultural product trade.

From the perspective of production factors, the production factors of cultural product trade in China mainly include 
human resources, capital resources and cultural resources. Compared with other production factors of product trade, cultural resources are more special, mainly referring to the ideas, poems, songs, customs, paintings and music and so on that show China's five thousand year civilization and national spirit. At present, China's capital investment in the development of cultural products trade is expanding day by day, human resources are relatively rich but lack of high-end human resources, and the development of cultural resources is not in-depth and effective. It is necessary to actively build an independent cultural brand, deeply dig traditional and national cultural endowments around brand building, promote the conversion of China's local cultural resources into economic benefits, and provide strong momentum for the continued improvement of China's cultural product trade international competitiveness.

From the perspective of demand status, it is mainly divided into domestic demand and foreign demand. Domestic demand directly affects the scale and quality of cultural product trade development, which is an important basis for expanding foreign markets and improving influence. It is necessary to stimulate domestic demand for cultural products by means of strengthening publicity, first-line investigation and research, and standardizing cultural product markets and so on, laying the foundation for cultivating and expanding the international market for cultural products trade.

From the perspective of corporate strategic organization and competitive status, the development strategy, organizational situation and competitive status of cultural enterprises have a great impact on the international competitiveness of cultural products trade to a large extent. At present, transnational cultural groups occupy the position of "monopoly" in the international cultural product market. In addition to the influence of trade barriers among countries, the pressure for Chinese cultural enterprises to go abroad and to the world is still enormous. In this regard, from the height of national strategy, it is necessary to cultivate key cultural enterprises. At the same time, Chinese cultural enterprises should continue to obtain advanced technology and advantageous resources through foreign investment, expand marketing channels and further integrate into foreign markets.

From the perspective of related industry support, in addition to cultural industry, the related supporting industries of cultural product trade mainly involve high-tech industry and information industry and so on. In the era of information technology, the promotion of cultural products, especially in foreign markets, must rely on the support of high-tech industry and information industry. The development of cultural industry itself is also inseparable from advanced information technology. At the same time, improving the added value of cultural products is inseparable from the support of high and new technology, continuously promoting the development of information technology in China, will play a very positive role in promoting the international competitiveness of cultural products trade. [4] At the same time, it is needed to pay attention to the leading role of the information technology industry, promote the integration of high-tech information technology and cultural industries, and promote the formation and development of emerging cultural formats.
At the government level, the Chinese government attaches great importance to the innovation and development of cultural products as well as the management of their output and input. Under the background of "trade war", the Chinese government should continue to improve the relevant policies and regulations, at the same time, continue to increase the support for cultural enterprises and cultural industries, gradually increase the financial allocation, tax relief, and increase the training of high-quality talents in the field of cultural products trade, which will provide a more powerful guarantee for the development of cultural products trade in China.

\section{CONCLUSION}

In the increasingly complex international situation, economic and trade frictions are inevitable. The recent ChinaUS economic and trade frictions have risen to "trade war", which is what people do not want to see, but must face up to. Based on the reality of China's cultural product trade development, it is necessary to fully understand the domestic and foreign environmental situation, only by strengthening the development of cultural resources, promoting the "going out" of cultural enterprises, increasing funding policy support, promoting the integration and development of related industries such as the cultural industry, high-tech industry and information industry, and continuously improving the international competitiveness of China's cultural product trade, in this way can China's cultural products trade move forward and develop continuously under pressure.

\section{REFERENCES}

[1] Bai Ming. Facing the Sino-US Trade War and Its Countermeasures [J]. Journal of Hangzhou Insititute of Financial Studies2019 (10): 48 (in Chinese)

[2] Liu Junting, Tong Jiying. Empirical Study on the Characteristics and the Growth Factors of the Export Trade of Chinese Cultural Products Based on the Factor Decomposition of the Multi-country CMS Model[J] International Economic and Trade Exploration, 2017 (11):33. (in Chinese)

[3] Fang Hui, Shang Yanan. Research on the Competitiveness of China's Cultural Trade Based on the Dynamic Diamond Model [J]. World Economic Research, 2012 (1): 47. (in Chinese)

[4] Chen Baifu. Research on the "Going out" Development of China's Cultural Industry based on the Perspective of International Trade of Cultural Products and Services [M]. Xiamen: Xiamen University Press, 2011. (in Chinese) 